\title{
Tolerance and adaptation mechanisms developed by Moringa oleifera (L) seeds under oxidative stress induced by salt stress during in vitro germination
}

\author{
Boumenjel A. ${ }^{1}$, Pantera A. ${ }^{2 *}$, Papadopoulos A. ${ }^{2}$ and Ammari Y. ${ }^{1}$ \\ ${ }^{1}$ National Research Institute for Rural Engineering, Waters and Forests, PB: 10, 2080, Ariana, University of Carthage, Tunis, Tunisia \\ 2Department of Forestry and Natural Environment Management, Agricultural University of Athens, GR-36000 Karpenissi, Greece \\ Received: 10/02/2020, Accepted: 24/11/2020, Available online: 23/05/2021 \\ *to whom all correspondence should be addressed: e-mail: pantera@aua.gr \\ https://doi.org/10.30955/gnj.003292
}

\section{Graphical abstract}

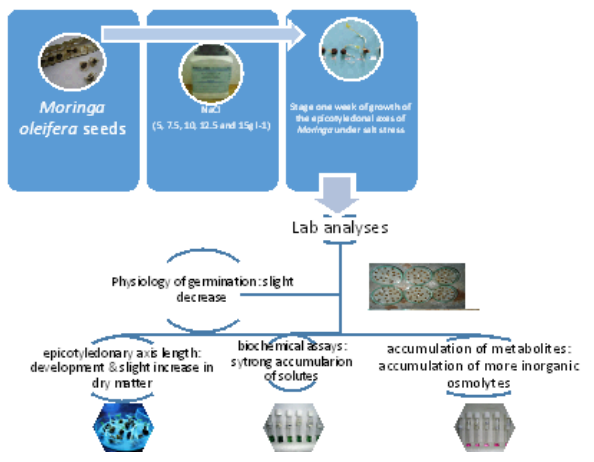

\section{Abstract}

The current study explores the capacity of Moringa oleifera (L), to overcome and/or tolerate oxidative stress induced by a saline substrate as a constraining factor. For this, Moringa seeds have been subjected, for 15 days after germination in vitro, with increasing concentrations of $\mathrm{NaCl}$, and specifically at 0 (control), 5, 7.5, 10, 12.5 and $15 \mathrm{~g}$ $\mathrm{I}^{-1}$. Both morpho-physiological and biochemical aspects were evaluated which were considered as probable indicators of tolerance or sensitivity to this stress. Our results reveal an increased synthesis of proline, lipids, proteins, CAT, GPX, APX, flavonoids, condensed tannins and a decrease in total polyphenols (-29.97\%), mainly due to their high carbon cost. The degradation state of the cell membranes was evaluated by the MDA assay, which increased by $91.25 \%$. On the contrary, the oxidative damage caused by Reactive Oxidative Species (ROS), detected by $\mathrm{H}_{2} \mathrm{O}_{2}$, decreased by $37.89 \%$. The germinative ability of the seeds was affected indicating moderate resistance to stress as it was evaluated by the development of epicotyledonary axes, even under $15 \mathrm{gl}^{-1}$ of $\mathrm{NaCl}$ without showing symptoms of stress or sensitivity. This result supports our hypothesis on the ability of the species to maintain or even improve its oxidative status.

Key words: Antioxidant, osmoregulatory activity, adaptive strategy.

\section{Introduction}

The salinity of the arid and semi-arid regions of the Mediterranean basin is a major problem affecting the quality of the soil and, therefore, agricultural production. This is particularly evidenced in the Maghreb region where both coastal and continental areas are influenced by this situation. For example, in Tunisia more than $25 \%$ of the irrigated soils are affected by this problem (Douaoui and Hartani, 2008).

Salt stress in plants produces Reactive Oxygen Species (ROS) which cause oxidative stress and, therefore, damages plant components (Ahmad et al., 2014; Latef and Chaoxing, 2014). This renders this subject as one of the priorities of scientific research, aiming to better understanding the phenomenon and being able to select more tolerant and/or resistant species, capable of rehabilitating such areas and minimizing the depressive effects of oxidative stress on agricultural yields (Arbaoui et al., 2000). This represents a crucial issue for agricultural production in the coming decades under the changing climate (Selma et al., 2015).

Under the framework of the above research quests, we investigated the germination Moringa oleifera, a widely distributed species in the Mediterranean region (Olson and Carlquist, 2001). It can develop in areas with low rainfall and high salinity (Lim, 2015; Pandey et al., 2011; Tian et al., 2015), and has significant antioxidant potential under severe stress (Tesfay et al., 2016). There are only a few studies focusing on the effect of oxidative stress to the germination of Moringa, which is an essential issue for the survival of the plant. Our study aims to clarify the capacity of antioxidant activities (enzymatic and non-enzymatic) and certain organic osmolytes, in the defense mechanisms and strategies and/or resistance of Moringa seeds to oxidative stress. This will enhance our knowledge on the possibility of using such a species in arid areas affected by salinity. 


\section{Materials and methods}

\subsection{Plant material and experimentation}

Moringa oleifera ( $\mathrm{L})$, belongs to the Moringaceae family (Laleye et al., 2015). It is native to India, in tropical and subtropical regions (Leone et al., 2015), where it was described as early as 2000 B.C. (Oluduro et al., 2016). All parts of this species have a variety of uses such as for consumption and medical purposes (Leone et al., 2015; Sharma et al., 2011). Similarly, the seeds have multifunctional roles (Anwar et al., 2007) for human nutrition and the production of high-quality biofuels and oil (Osman and Abohassan, 2012) as well as for water purification (Yusuf et al., 2015).

In this study three hundred and sixty Moringa seeds (360) were used. The seeds were obtained from an Egyptian origin of Moringa, collected at the end of 2016 and kept in a cold room with a temperature of $4 \pm 1^{\circ} \mathrm{C}$. In vitro germination was conducted at the Forest Ecology Laboratory (LEF) of the National Institute for Research in Rural Water and Forests Engineering (INRGREF) of Tunis (Tunisia).

The seeds were initially imbibed for 48 hours in distilled water (change of water in the bath every 24 hours) and subsequently disinfected by Betadine ( $80 \%$ vol/vol) for $5 \mathrm{~min}$. After an abundant rinsing with distilled water, they were further disinfected with $70 \%$ (vol/vol) sodium hypochlorite ( $\mathrm{NaOCl}$ ) 70\% (vol/vol) for additional $5 \mathrm{~min}$, and finally, thoroughly rinsed again with distilled water. Batches of 20 seeds were germinated in Petri glass dishes $\left(14 \times 14 \mathrm{~cm}^{2}\right)$, lined with filter paper (Wattman $\left.\mathrm{N}^{\circ} 4\right)$ soaked in distilled water (control) and/or increasing concentrations of $\mathrm{NaCl}\left(5,7.5,10,12.5\right.$ and $\left.15 \mathrm{gl}^{-1}\right)$. These Petri glass dishes were placed in a culture chamber at a temperature of $26 \pm 1^{\circ} \mathrm{C}$ and a relative humidity of $60 \%$ in total darkness (Quashie and Tchezoum, 2009; ISTA, 2014). After the emergence of the radical (Rachidai et al., 1994), the sprouts of each treatment were counted daily.

\subsection{Parameters studied and analyses performed}

These included:

\subsubsection{Physiology of germination $(n=4)$}

The curve that represented the evolution of the percentle of cumulative germination as a function of time. This parameter is used to enhance the understanding of the physiological significance of the germination behavior of seeds under salt stress (Hajlaoui et al., 2007).

\subsubsection{Growth in epicotyledonary axis length $(n=4)$}

It was evaluated by measuring epicotyledonary axis lengths (every day) during the whole germination phase, taking into account the curvatures of the radicle and/or the epicotyl, measured by a graduated ruler (in $\mathrm{mm}$ ).

\subsubsection{Biochemical assays}

The phenolic compounds, malondialdehyde (MDA) and $\mathrm{H}_{2} \mathrm{O}_{2}$ were evaluated in the developed cotyledon of each seed (kernels). In specific, the Phenolic compounds by $i$. Total polyphenols (TP), according to the method of Dewanto et al. (2002), ii. Flavonoids (Flav), according to a colorimetric method described by Dewanto et al. (2002), and iii. Dose of condensed tannins (CT), according to the method of Sun et al. (1998). The Malondialdehyde (MDA), according to the method of Hernandez et al. (2002). The Hydrogen peroxide $\left(\mathrm{H}_{2} \mathrm{O}_{2}\right)$, based on the protocol of Novillo et al. (2014) slightly modified. The Antioxidant capacity (AAT) was measured according to Prieto et al. (1999). The antioxidant enzymes, proteins, lipids and proline have been measured at the epicotyledonal axes of the seeds, stored at $-80{ }^{\circ} \mathrm{C},(\mathrm{n}=3)$, and in specific the Antioxidant enzymatic activities by i. Catalase (CAT. EC 1.11.1.6) produced according to the protocol of Novillo et al. (2014), ii. Guaiacol peroxidase (GPX. EC 1.11.1.7) measured according to Nagalakshmi and Prasad (2001), and iii. Ascorbate peroxidase (APX. EC 1.11.1.11) measured according to Nakano and Asada (1981).

The Accumulation of metabolites was evaluated by the total protein (TP), that was measured according to Bradford (1976), total lipids (TL), was estimated by Goldsworthy et al. (1972) and proline (Pro), was measured according to Troll and Lindsley (1955) modified by Dreier and Goring (1974).

\subsubsection{Statistical analysis}

The statistical analyzes were carried out using the software XL STAT 2014.5.04. The results are given in terms of mean \pm standard deviation (SD). The simultaneous comparison of several means was conducted by the ANOVA parametric procedure (Duncan's $F$ test/Analysis of the differences between the modalities with a $95 \%$ confidence interval), when the conditions of normality and equality of the variances are verified.

\section{Results and discussion}

\subsection{Physiology of germination}

A single-factor variance analysis on early germination, at the $P \leq 0,001$ threshold, showed that salt stress has a very highly significant effect on this parameter. Indeed, the seeds, germinated in distilled water (control), have early germination, from the second day, at a rate of $36.25 \%$ whereas the increasing concentrations of $\mathrm{NaCl}$, cause a decrease in germination, reaching $96 \%$ for $15 \mathrm{~g} \mathrm{I}^{-1}$, accompanied by a delay of one day.

The response of $M$. oleifera seeds to oxidative stress induced by salt stress was very variable. Indeed, our results in Figure 1, suggest that there is a partial and very highly significant inhibition $(P \leq 0.05)$ of germination which is reflected by the reduction of the cumulative germination rates as a function of time. The evolution of germination as a function of time is a typical sigmoidal curve. It is noteworthy that the control seeds show a best germination rate of $90 \% \pm 1.31$. A similar behavior, not statistically different, was detected for the treated by $5 \mathrm{~g} \mathrm{I}^{-1} \mathrm{NaCl}$ solution, which reached a germination rate of $82.5 \% \pm 1.22$. The opposite phenomenon is observed for the levels of treatments $\geq 7.5 \mathrm{~g} \mathrm{I}^{-1}$ with those treated with $15 \mathrm{~g} \mathrm{I}^{-1}$ displaying a rate of $48.75 \% \pm 0.18$, corresponding to a $45.83 \%$ drop in germination compared to the controls. 
Similar results are reported by Hussein and Abou-Baker (2014), Hegazi (2015) and Tesfay et al. (2016) on seeds of the same species, treated with increasing concentrations of diluted sea water (in \%) and by the work of Bafeel et al. (2018) on the seeds of Moringa peregrina and M. oleifera similarly treated by increasing concentrations of sea water. In this context, Xia et al. (2010) report that salt stress triggers oxidative stress in plants as a consequence of the excessive production of ROS responsible for cell damage, metabolic disorders and the senescence process. Bafeel et al. (2018) assume that this stress decreases the rate of water absorption, the enzymatic activation and disturbs the metabolism of the seeds. Similarly, El-Dabh et al. (2011) report that the absorption of water by Moringa seeds is slowed with increasing levels of salinity and, as a result, seeds' germination is inhibited.

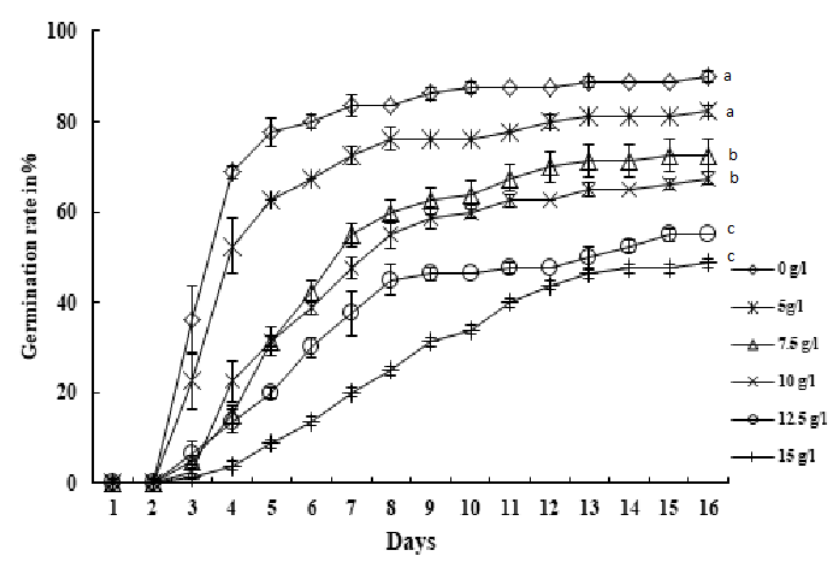

Figure 1. Variation in the cumulative average of final germination rates (\%) of Moringa grains in the presence of increasing concentrations of $\mathrm{NaCl}\left(\mathrm{g} \mathrm{l}^{-1}\right)$. Df $=5 ; \mathrm{Pr}=0.0001<0.05$ very highly significant. The lines followed by different letters are significantly different ( $P \leq 0.001$ ) according to Duncan's test. The treatments are control $\left(0 \mathrm{~g} . \mathrm{l}^{-1}\right)$, low stress $\left(5 \mathrm{~g} . \mathrm{I}^{-1}\right)$, average stress

(7.5 and $10 \mathrm{g.l}^{-1}$ ) and strong stress (12.5 and $\left.15 \mathrm{g.l}^{-1}\right)$

According to Rejili et al. (2006) this phenomenon may be linked to a cellular accumulation of salt. This disrupts the enzymes involved in the physiology of the germinating seeds so that it disturbs the dormancy of the embryo and leads to a decrease in the germination capacity. As for

Table 1. Variation in the growth in length of the epicotyledonal axes and in the MDA activity of $\mathrm{H}_{2} \mathrm{O}_{2}$ under the different $\mathrm{NaCl}$ concentrations

\begin{tabular}{|c|c|c|c|c|}
\hline $\begin{array}{l}\text { Treatment } \\
\text { in } \mathbf{g ~ l}^{-1} \\
\end{array}$ & $\begin{array}{l}\text { Length of the Rd } \\
\text { in } \mathrm{mm}^{-1}(*)\end{array}$ & $\begin{array}{l}\text { Length of the Ep } \\
\text { in } \mathrm{mm}^{-1}(* *)\end{array}$ & $\mathrm{H}_{2} \mathrm{O}_{2}$ in $\mu \mathrm{mol} \mathrm{g}^{-1}(* * *)$ & $\begin{array}{c}\text { MDA in } \mu \mathrm{mol} \mathrm{gFM}^{-1} \\
(* * * *)\end{array}$ \\
\hline 0 & $78.77 \pm 6.64^{a}$ & $115.62 \pm 2.11^{a}$ & $7.98 \pm 5.10^{-2 a}$ & $85.10^{-4} \pm 11.10^{-5 d}$ \\
\hline 5 & $65.13 \pm 6.5^{a}$ & $73.88 \pm 1.88^{b}$ & $6.69 \pm 9.10^{-2 b}$ & $88.10^{-4} \pm 24.10^{-5 \mathrm{~cd}}$ \\
\hline 7,5 & $32.11 \pm 4.25^{b}$ & $40.53 \pm 4.44^{c}$ & $6.0 \pm 11.10^{-2 c}$ & $10.10^{-3} \pm 23.10^{-5 b}$ \\
\hline 10 & $25.46 \pm 0.57^{b c}$ & $24.84 \pm 1.95^{d}$ & $6.13 \pm 35.10^{-2 c}$ & $16.10^{-3} \pm 13.10^{-5 a}$ \\
\hline 12,5 & $11.96 \pm 0.56^{\mathrm{cd}}$ & $12.52 \pm 0.93^{\mathrm{e}}$ & $5.57 \pm 17.10^{-2 d}$ & $9.10^{-3} \pm 2.10^{-4 c}$ \\
\hline 15 & $9.19 \pm 0.35^{d}$ & $6.50 \pm 3.25^{\mathrm{e}}$ & $4.95 \pm 49.10^{-2 \mathrm{e}}$ & $7.10^{-3} \pm 15.10^{-5 e}$ \\
\hline
\end{tabular}

* Df = 5; Pr = $0.0001<0.05$ Very highly significant, ** Df = 5; Pr = $0.0001<0.05$ Very highly significant, $* * * D f=5 ; \operatorname{Pr}=0,0001<0.05$ Very highly significant, $* * * * \mathrm{Df}=5 ; \mathrm{Pr}=0.0001<0.05$ Very highly significant, $\mathrm{FM}$ : fresh material

The reduction of growth in the length of the epicotyledonal axes is consistent with that of Hussein and Abou-Baker (2014), Hegazi (2015), Silva et al. (2017), Noreen et al.
Prado et al. (2000), an osmotic dormancy process developed under these stress conditions can also explain this disturbance in germination. Alternatively, this could be due to the alteration of enzymes and hormones present in the seed. Based on the same authors, this phenomenon thus represents an adaptation strategy to face such constraints.

3.2. Variation in the growth in length of the epicotyledon axes and in the MDA activity of $\mathrm{H}_{2} \mathrm{O}_{2}$

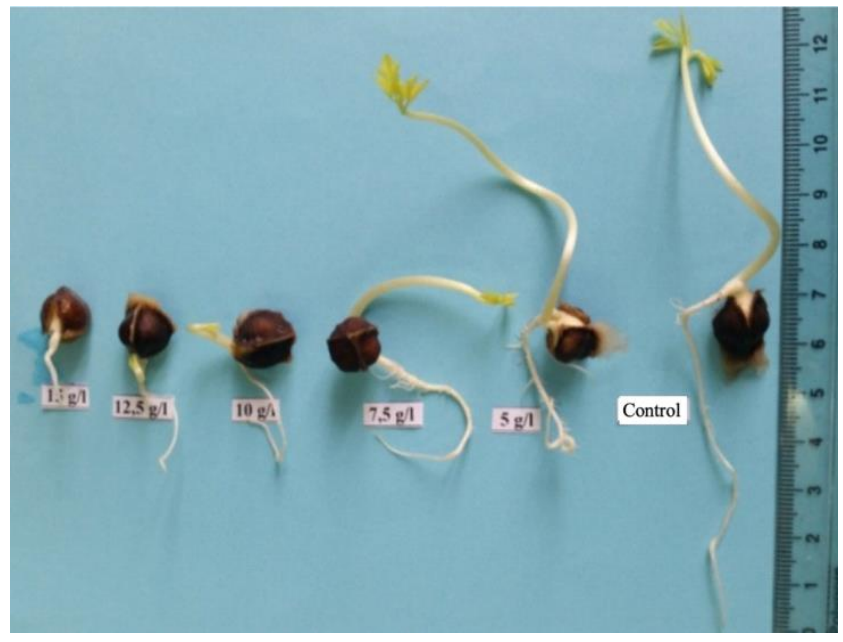

Figure 2. Stage one week of growth of the epicotyledonal axes of Moringa under salt stress

Our results (Table 1$)$ reveal a significant negative correlation $(P \leq 0.05)$, between the growth in length of the epicotyledon axes and the increasing salt concentrations, with the reduction reaching $88 \%$ in radicles $(\mathrm{Rd})$ and $94 \%$ in the epicotyls (Ep) under the $15 \mathrm{~g} \mathrm{l}^{-1}$ of $\mathrm{NaCl}$ compared to the control. The same fate is observed at the level of hydrogen peroxide $\left(\mathrm{H}_{2} \mathrm{O}_{2}\right)$ which is manifested by a decrease of $37.89 \%$, under the same dose of salt. In addition, the MDA activity has developed variable responses, under the effect of different salt treatments. Indeed, under concentrations $\leq 10 \mathrm{~g} \mathrm{I}^{-1}$, it is gradually increasing until reaching $91.25 \%$. However, it decreases as the concentration of $\mathrm{NaCl}$ increases, for a marked fall of $17.87 \%$ under $15 \mathrm{~g} \mathrm{I}^{-1}$ (Figure 2).

(2018) on the same species, treated with increasing concentrations of diluted sea water (in \%). They are also consistent with those of Bafeel et al. (2018) on Moringa 
pérégrina and $M$. oleifera. These latter authors suggest that salinity induces oxidative stress in plants, which disrupts cellular metabolism (McCord, 2000). Dos Santos et al. (2010), report that this phenomenon is probably associated with metabolic changes and the uncontrolled cellular process and so creates that physio-logical disorder (Hussein and Abou-Baker, 2014).

According to Munns (2008), the harmful effect of $\mathrm{NaCl}$ on growth can be expressed in three ways: i. reduction of the water available in the root zone leading to a water deficit, ii. phytotoxicity of ions ( $\mathrm{Na}^{+}$and $\mathrm{Cl}^{-}$) and iii. a nutrient imbalance reducing the absorption and transport of nutrients and the competition of $\mathrm{Na}^{+}, \mathrm{K}^{+}$for binding sites essential to cellular function. As to Houle et al. (2001), this is a survival strategy. It allows the plant to accumulate energy and resources to fight stress, before the imbalance between the inside and the outside part of the body reaches a threshold point where the damage will be irreversible (Bois, 2005; Zhu, 2004).

The reduction in $\mathrm{H}_{2} \mathrm{O}_{2}$ production (Table 1 ) during germination is consistent with the work of Rivas et al. (2013) and Tesfay et al. (2016) on Moringa seeds. In addition, $\mathrm{H}_{2} \mathrm{O}_{2}$ plays an important role at the cellular level by participating in programmed cell death or with a hormonal effect (Parent et al., 2008). This active process is found throughout the life of plants and is involved in their germination (aleurone layer) and growth (Dat et al., 2003; Van Breusegem et al., 2006). Thus, we can attribute the disturbances observed during our study at the level of germination and length growth of Moringa to this ROS. However, $\mathrm{H}_{2} \mathrm{O}_{2}$ has the capacity to diffuse far from its production site and can cross membranes using aqueous channels (aquaporins), thanks to its great chemical similarity with $\mathrm{H}_{2} \mathrm{O}$ (Bienert et al., 2006; 2007). However, the Fenton and Haber-Weiss reactions, causing lipid peroxidetion, protein breakdown and DNA damage (Parent et al., 2008) can also convert it to the hydroxyl radical. For Sudhakar et al. (2001), these ROS damage the cellular components of proteins, membrane lipids and nucleic acids.

Concerning the danger that $\mathrm{H}_{2} \mathrm{O}_{2}$ represents as a ROS for plant cells, its concentration can be regulated by enzymes, such as APX, CAT or GPX (Parent et al., 2008). This may explain our results, which highlighted a negative correlation between the $\mathrm{H}_{2} \mathrm{O}_{2}$ content and the concen-trations of the different antioxidant enzymes analyzed (Table 3). This explanation is confirmed by Yang and Poovaiah (2002) who claim that the CAT sometimes eliminates $\mathrm{H}_{2} \mathrm{O}_{2}$ with the help of phenolic compounds.

Our results are in agreement to the work of Zineb et al. (2015) and Bafeel et al. (2016), who suggest that MDA provides information on the state of degradation of cell membranes. According to Hernández et al. (2000), MDA can be considered as a good indicator of the tolerance of plants to different abiotic constraints and in particular to saline stress. It has also been shown that plants with high levels of MDA without showing symptoms can withstand the effect of oxidative stress (Arbona et al., 2007). On the other hand, Da Costa et al. (2005), argues that lipid peroxidation is not a universal marker for the tolerance of all plant species to saline stress. This is also true for Ashrafi et al. (2014), who have shown by their work on Medicago sativa, that the MDA content was lower in salt tolerance cultivars compared to susceptible cultivars.

3.3. Study of the activity of phenolic compounds in the shelled seeds of Moringa (kernels)

Our results (Table 2) have highlighted the presence of various types of phenolic compounds (TP, Flav and CT) in the ethanolic extracts of the husks of $M$. oleifera seeds. This is in total agreement with the data from Singh et al. (2013) and Olagbemide and Alikwe (2014) in the same species. These results suggest that the contents of these compounds show highly significant variations $(P \leq 0.05)$ as a function of increasing $\mathrm{NaCl}$ concentrations. Indeed, the TP content was initially positively correlated with increasing salt concentrations until reaching an increase of $19.53 \%$ under $7.5 \mathrm{~g} \mathrm{I}^{-1}$ compared to the control. However, this content decreased as the concentration of $\mathrm{NaCl}$ increased, falling by $29.97 \%$ under $15 \mathrm{~g} \mathrm{l}^{-1}$.

On the other hand, our results reveal an increased synthesis of Flav and CT. The Flav content increased by $97.76 \%$ and CT by $22.78 \%$ under $15 \mathrm{~g} \mathrm{I}^{-1}$, compared to the controls. The decrease in the synthesis of TP under concentrations higher than $7.5 \mathrm{~g} \mathrm{I}^{-1}$ agree with those of Karoune (2016), on the seeds of two species of Acacia ( $A$. albida and $A$. raddiana). To explain this phenomenon Gallé et al. (2007), hypothesize that the stress is too intense, limiting the availability of carbon resources (basic substances for the production of new phenols). Sakihama et al. (2002) suppose that it is possible, under certain restrictive conditions, such substances convert to prooxidants by ester hydrolysis and bioreductive metabolism, which limits their biosynthesis by plants. However, the increase in Flav levels in Moringa seeds is confirmed by the work of Gao et al. (2015), Mendoza-Sánchez et al. (2016) and Karoune (2016). Løvdal et al. (2010), assume that these compounds act as antioxidant molecules, ensure the fixation of ROS produced during stress and thus neutralize their effects before the manifestation of oxidative damage at the cellular level. As for Ben Sekerifa and Khellafi (2018), they suggest that these are potentially antioxidant substances having the capacity to trap radical species and ROS. In the same context, Nijveldt et al. (2001) report that Flav prevent lipid oxidation, as they mainly act as scavengers for free radicals such as DPPH and superoxide. The synthesis of CT by Moringa seeds is supported by the work of Nouman et al. (2012) on the same species but also by Abd EL-Azim and Ahmed (2009) and Guardado-Félix et al. (2017) on the seeds of Pisum sativum. According to Aguilera-Carbo et al. (2008), CT are generally amorphous compounds located in vacuoles. Thus, they are very effective in preventing lipid peroxidation. They also have scavenger activity of the radical DPPH and the superoxide anion (Okuda, 2005). Spranger et al. (2008), indicate that these polymeric molecules are responsible for a strong antioxidant activity and therefore for the protection of the plant against environmental constraints.

Based on these facts, it can be assumed that Moringa's ability to overcome the oxidative stress triggered by 
salinity, is governed by an adaptive mechanism, based essentially on the biosynthesis of phenolic compounds.

Table 2. Variation of phenolic compounds as a function of different $\mathrm{NaCl}$ concentrations

\begin{tabular}{|c|c|c|c|}
\hline Treatment in $\mathrm{g}^{-1}$ & TP in mgEAG gDM $^{-1}(*)$ & Flav in $\mathrm{mgEC} \mathrm{gDM}^{-1}(* *)$ & $\mathrm{CT}$ in $\mathrm{mgEC} \mathrm{gDM}^{-1}(* * *)$ \\
\hline 0 & $16,4 \pm 0,21^{b}$ & $0.18 \pm 0.01^{b}$ & $1.34 \pm 0.03^{d}$ \\
\hline 5 & $13,9 \pm 0,13^{c}$ & $0.19 \pm 0.002^{b}$ & $1.64 \pm 0.006^{c}$ \\
\hline 7.5 & $19,65 \pm 0,13^{\mathrm{a}}$ & $0.21 \pm 0.003^{b}$ & $1.82 \pm 0.03^{b}$ \\
\hline 10 & $11,66 \pm 0,11^{\mathrm{d}}$ & $0.33 \pm 0.002^{\mathrm{a}}$ & $1.85 \pm 0.02^{\mathrm{a}}$ \\
\hline 12.5 & $11,04 \pm 0,02^{\text {de }}$ & $0.34 \pm 0.002^{\mathrm{a}}$ & $1.86 \pm 0.012^{\mathrm{ab}}$ \\
\hline 15 & $11,5 \pm 0,24^{e}$ & $0.36 \pm 0.003^{a}$ & $1.93 \pm 0.012^{\mathrm{a}}$ \\
\hline
\end{tabular}

${ }^{*} \mathrm{Df}=5 ; \mathrm{Pr}=0,0001<0,001$ : Very highly significant, ${ }^{* *} \mathrm{Df}=5 ; \mathrm{Pr}=0.0005<0.001$ : Very highly significant, $* * * \mathrm{Df}=5 ; \mathrm{Pr}=0.0001<$ 0.001: Very highly significant, DM: dry matter, mgEAG gDM-1: Mg equivalents Gallic Acid per gram dry matter, mg ECg-1DM: Equivalent Catechin mg per gram of dry matter

Table 3. Evolution of the total antioxidant and enzymatic activity of Moringa under increasing concentrations of $\mathrm{Na} \mathrm{Cl}$

\begin{tabular}{|c|c|c|c|c|}
\hline Traitement en $\mathrm{g} \mathrm{I}^{-1}$ & AAT in mgEAG gDM ${ }^{-1}\left({ }^{*}\right)$ & APX in U $\mathrm{gFM}^{-1}(* *)$ & CAT in $\mathrm{UFM}^{-1}\left({ }^{* * *}\right)$ & $\mathrm{GPX}$ in $\mathrm{U} \mathrm{gFM}^{-1}(* * * *)$ \\
\hline 0 & $173.4 \pm 2.4^{d}$ & $0.525 \pm 0.004^{d}$ & $22.7 \pm 0^{b}$ & $0.42 \pm 0.014^{b}$ \\
\hline 5 & $211 \pm 2.08^{c}$ & $0.61 \pm 0.007 c$ & $18.98 \pm 2.9^{b}$ & $0.48 \pm 0.013^{b}$ \\
\hline 7,5 & $225.7 \pm 2.05^{b}$ & $0.71 \pm 0.004^{b}$ & $26.6 \pm 1.46^{b}$ & $0.62 \pm 0.004^{b}$ \\
\hline 10 & $228.4 \pm 1.54^{\mathrm{ab}}$ & $0.84 \pm 0.011^{a}$ & $43.65 \pm 2.9^{a}$ & $0.61 \pm 0.004^{a}$ \\
\hline 12,5 & $228.5 \pm 1.95^{\mathrm{ab}}$ & $0.525 \pm 0.009^{d}$ & $45.5 \pm 1.09^{a}$ & $0.6 \pm 0.012^{\mathrm{a}}$ \\
\hline 15 & $237.6 \pm 2^{a}$ & $0.47 \pm 0.004^{e}$ & $41.75 \pm 1.8^{\mathrm{a}}$ & $0.62 \pm 0,003^{a}$ \\
\hline
\end{tabular}

* Df = 5; $\operatorname{Pr}=0.0001<0.05$ Very highly significant, ** Df = 5; $\operatorname{Pr}=0.0001<0.05$ Very highly significant, *** $\mathrm{Df}=5 ; \mathrm{Pr}=0.0001<0.05 \mathrm{Very}$ highly significant, **** Df $=5 ; \operatorname{Pr}=0.0001<0.05$. Very highly significant, DM: dry matter, mgEAG gDM-1: Mg equivalents Gallic Acid per gram dry matter, $\mathrm{mg} \mathrm{ECg}^{-1} \mathrm{DM}$ : Equivalent Catechin mg per gram of dry matter, FM: fresh material

\subsection{Involvement of total antioxidant and enzymatic activity in the defense of Moringa against ROS}

Our results in Table 3 show a significant accumulation $(P \leq$ 0.05) of AAT in shelled Moringa seeds, under the different $\mathrm{NaCl}$ concentrations. Indeed, it shows an increase of $37 \%$ under $15 \mathrm{~g} \mathrm{l}^{-1}$ compared to the control.

Additionally, our results reveal an increased biosynthesis of the antioxidant enzymatic compounds at the level of the epicotyledonal axes of Moringa, marked by an $83.92 \%$ increase in the CAT and a $47.61 \%$ increase in the GPX under $15 \mathrm{~g}^{-1}$ of $\mathrm{NaCl}$ (the most severe) compared to the controls. On the other hand, the APX represents a disturbancesynthesis which is manifested by an accumulation of $60 \%$ under $10 \mathrm{gl}^{-1}$ and then a progressive reduction reaching at $10.47 \%$ for the $15 \mathrm{~g} \mathrm{|}^{-1}$ level.

The high accumulation of AAT suggests the involvement of these compounds in its response to salt stress, as also confirmed by Nouman et al. (2012) on the same species, by Karoune (2016) on Acacia albida and by Guardado-Félix et al. (2017) on Pisum sativum. Joseph and Jini (2011) explain this phenomenon by the fact that the plant has developed a system of defenses in order to ensure the detoxification and the fixation of ROS. For Bor et al. (2003), plants that produce high levels of antioxidants are able to provide better resistance to damage induced by salinity. Mittler (2002) supposes that salt-tolerant species have a better antioxidant system which controls the production of ROS and allows plants to survive under abiotic stress. As a result, Moringa's antioxidant system is relatively stronger than other salinity tolerant species enabling its survival under such high stress conditions (Nouman et al., 2012).

It is evident that salt stress has induced the activity of antioxidant enzymes (CAT, APX and GPX) which constitutes a basic strategy for dealing with ROS. Similar results are reported by Nouman et al. (2012) and Silva et al. (2017) on the same species and by Bafeel et al. (2018) on Moringa oléiféra and $M$. pérégrina. Therefore, these enzymes seem to be an indication of salt tolerance for Moringa (Ashrafi et al., 2014) since they are considered among the main detoxification enzymes (Gill and Tuteja, 2010), as also confirmed by Ksouri et al. (2010), Liu et al. (2012) and Nouman et al. (2012). This explains why the seedlings used in our experiments did not show symptoms of stress or sensitivity, even under doses $\geq 10 \mathrm{~g} \mathrm{I}^{-1}$ of $\mathrm{NaCl}$. Also, it demonstrates moderate resistance to stress by the development of epicotyledonal axes even under $15 \mathrm{~g} \mathrm{l}^{-1}$ of $\mathrm{Na} \mathrm{Cl}$. On the other hand, CAT is an intracellular hemoprotein which directly dismutates $\mathrm{H}_{2} \mathrm{O}_{2}$ into $\mathrm{H}_{2} \mathrm{O}$ and oxygen and is responsible for the detoxification of free radicals (Gill and Tuteja, 2011). In the same line of idea, Khalifa et al. (2011) note that, sometimes, an increase in the activity of the CAT is perceived even in the absence of an intake of $\mathrm{H}_{2} \mathrm{O}_{2}$. Compared to CAT, the role of $\mathrm{GPX}$ remains regular but secondary in the mobilization of $\mathrm{H}_{2} \mathrm{O}_{2}$ because of the weak capacity to eliminate ROS (Gondim et al., 2012). Thus, its synthesis is at the origin of a better tolerance to stress (Gill and Tuteja, 2010). As a result, it presents an improvement in germination and growth under saline stress (Roxas et al., 2000), which holds true in our study. Mhadhbi et al. $(2004,2008,2009)$ suggest it as a potential biochemical marker for tolerance to salt stress. Hence, it is essentially involved in lignification and strengthening of the cell wall and provides better protection of tissue integrity (membrane). In addition, the accumulation of APX in our experiment under concentrations $\leq 10 \mathrm{gl}^{-1}$ of $\mathrm{NaCl}$ is probably explained by its 
key role in eliminating $\mathrm{H}_{2} \mathrm{O}_{2}$ (Wang and Han, 2009) and by its important role in the protection against oxidative stress induced by salt in higher plants (Li et al., 2012). According to Ben Ahmed et al. (2010) and Hakiman and Maziah (2010), APX can reduce $\mathrm{H}_{2} \mathrm{O}_{2}$ levels by catalyzing its reduction through the use of ascorbate as a co-substrate. Kartashov et al. (2008) have shown that plants which exhibit intense activity of APX, exhibit good acclimatization to saline stress conditions. On the other hand, beyond the concentration of $10 \mathrm{~g} \mathrm{I}^{-1}$, APX activity decreased significantly, which could be due to damage caused by the antioxidant system (Nouman et al., 2012). The capacity for production and accumulation of antioxidant enzymes within the cells is a strategy that Moringa is developing to survive under severe saline stress.

\subsection{Role of organic solutes in Moringa salt tolerance}

The results (Table 4) reveal a positive correlation between the biosynthesis of organic osmolytes and increasing salt concentrations, expressed by a $39.47 \%$ increase in proline as well as a large significant accumulation of proteins and lipids which exceed $100 \%$ under $15 \mathrm{~g} \mathrm{I}^{-1}$ of $\mathrm{NaCl}$, compared to the control.

These results corroborate with those of Silva et al. (2017) on the same species. These authors suggest that the production capacity and the accumulation of organic solutes within cells is a strategy that Moringa is developing to allow its survival under saline stress. This has been confirmed by Chen and Jiang (2010) and Majumder et al. (2010), who point out that this phenomenon is another adaptation strategy to salinity. In the same line of thought, Koyro et al. (2012) state that such synthesis is one of the main biochemical responses of plants to abiotic stress. For Kaya et al. (2013), the accumulation of compatible solutes often forms a basic strategy for saline stress, increasing the activities of antioxidant enzymes in plants exposed to saline stress. They also add that the oxidative defense in plants stressed by salt had been very effective in countering various ROS produced due to salt stress.

Table 4. Evaluation of the activity of proline, proteins and total lipids under increasing concentrations of $\mathrm{Na} \mathrm{Cl}$

\begin{tabular}{|c|c|c|c|}
\hline Treatment in ${\mathrm{g} . \mathrm{I}^{-1}}^{-1}$ & Pro in $\mu \mathrm{gFM}^{-1}(*)$ & $\operatorname{Pr}$ in $\mu \mathrm{g} \mathrm{I}^{-1}(* *)$ & TL in $\mu \mathrm{g} \mathrm{I}^{-1}(* * *)$ \\
\hline 0 & $6.08 \pm 0.1^{c}$ & $22.32 \pm 1.62^{f}$ & $86.81 \pm 0.55^{c}$ \\
\hline 5 & $5.96 \pm 0.26^{c}$ & $67.06 \pm 0.21^{\mathrm{e}}$ & $127.5 \pm 1.73^{b}$ \\
\hline 7.5 & $5.71 \pm 0.1^{d}$ & $71.34 \pm 6.0^{d}$ & $203.9 \pm 2.76^{b}$ \\
\hline 10 & $5.81 \pm 0.05^{c}$ & $80.82 \pm 00.07 c$ & $215.9 \pm 5.5 a$ \\
\hline 12.5 & $8.84 \pm 0.07^{b}$ & $95.39 \pm 1.67^{b}$ & $239.7 \pm 2.9^{\mathrm{a}}$ \\
\hline 15 & $11.13 \pm 0.74^{a}$ & $101.09 \pm 0.86^{a}$ & $264.8 \pm 5.9^{a}$ \\
\hline
\end{tabular}

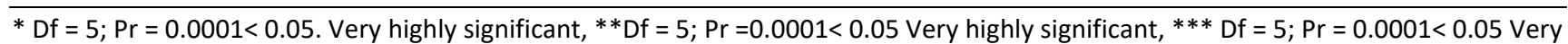
highly significant, FM: fresh material.

It has been found that the synthesis of proline gradually increases with increasing $\mathrm{NaCl}$ concentrations. This has been reported by a similar work on the same species by Silva et al. (2017). Thus, Ashraf and Foolad (2007) assume that proline, in addition to being an osmolyte, is also involved in the elimination of free radicals and protects plant cells against the harmful effects of salt by maintaining osmotic balance. Likewise, it participates as an osmolyte in the retention of water in the cytoplasm as well as it protects against membrane desiccation and denaturation of proteins (Ben Ahmed et al., 2010). According to Chen and Dickman (2005) and Gill and Tuteja (2010), proline is a non-enzymatic osmoprotective, has good inhibitory potential and is considered essential for the plant in order to counteract the effect of ROS under stress conditions. However, Majumder et al. (2010) report that the main role of proline is to maintain a low water potential inside the cells in order to generate a suction force for water absorption to improve tolerance to salt stress.

In addition, protein synthesis is in agreement with the work of Silva et al. (2017) on Moringa and of Parvaiz et al. (2014) on Morus alba which point out that such a phenomenon often occurs during acclimatization process in stressful environments and is, therefore, involved in the induction of salt tolerance. Similarly, Ben kaddour (2014) have shown that the increase in stress promotes a significant accumulation of total proteins, in contents that are proportional to the concentration of $\mathrm{NaCl}$ applied. For
Parvaiz et al. (2014) this protein accumulation scheme clearly shows that they could be used as potential indicators of tolerance to salinity.

Despite the increasing salt constraint, Moringa seeds manage to preserve their lipid status or even involve them in its tolerance mechanism (Mâalem, 2011; Singh et al., 2002). These authors add that lipids also play an important role as constituents of most membrane cells structures. They also have a vital role in tolerance to various physiological stresses.

\section{Conclusion}

The ability of Moringa oleifera to overcome the oxidative stress induced by salt stress during germination is governed by several tolerance strategies. These adaptive mechanisms include changes in physiological and biochemical processes. As a result, Moringa adaptation is associated with metabolic adjustments leading to the accumulation of several organic solutes such as proteins, lipids and proline, as well as to strong enzymatic and nonenzymatic antioxidant activities. This makes this species capable of rehabilitating and enhancing the arid and semi - arid zones such as the Tunisian ones. Given its physiological and antioxidant characteristics, this species is undoubtedly a species of the future, especially in arid and semi-arid zones. 


\section{References}

Abd EL-Azim W.M. and Ahmed S.Th. (2009), Effect of Salinity and Cutting Date on Growth and Chemical Constituents of Achillea fragrantissima Forssk, under Ras Sudr Conditions, Research Journal of Agriculture and Biological Sciences, 5(6), 11211129.

Aguilera-Carbo A., Augur C., Prado-Barragan L.A., Favela- Torres E. and Aguilar C.N. (2008), Microbial production of ellagic acid and biodegradation of ellagitannins. Applied Microbiology and Biotechnology, 78, 189-199.

Ahmad P., Ozturk M., Sharma S. and Gucel S. (2014), Effect of sodium carbonate induced salinity-alkalinity on some key osmoprotectants, protein profile, antioxidant enzymes, and lipid peroxidation in two mulberry (Morus alba L.) cultivars, Journal of Plant Interactions, 9, 460-467.

Anwar F., Latif S., Ashraf M. and Gilani A.H. (2007), Moringa oleifera: a food plant with multiple medicinal uses, Phytotherapy Research, 21(1), 17-25.

Arbaoui M., Benkhelifa M. and Belkhodja M. (2000), Réponses physiologiques de quelques variétés de blé dur à la salinité au stade juvénile, Option méditerranéenne, 267-270.

Arbona V., Jacas J. and Gomez-Cadenas A. (2007), Response to the antioxidant machinery of two citrus rootstocks (Mandarin Cleopatra and Carrizo citrange) to salt stress, Proceedings of International Society of Citriculture, 25, 644-648.

Ashraf M. and Foolad M.R. (2007), Roles of glycine betaine and proline in improving plant abiotic stress Environ, Experimental Botany, 59(2), 206-216.

Ashrafi E., Zahedi M. and Razmjoo J. (2014), Effects of salt stress on lipid peroxidation and antioxidative enzymes of alfalfa (medicago sativa I.) Cultivars, Bangladesh Journal of Botany, 43(2), 191-196.

Bafeel S., Alrashedi A., Abdualmonem A. Al Toukhy and AlZahrani Y. (2018), Influence of Diluted Seawater Irrigation on Seed Germination of Moringa oleifera, and Moringa Peregrina, Advances in Environmental Biology, 12(3), 10-12.

Bafeel S.O., Galal H.K. Basha A.Z. and Arabia S. (2016), Effect of Seawater Irrigation on Growth and Some Metabolites of Jojoba Plants (Simmondisia chinensis), American-Eurasian Journal of Agricultural \& Environmental Sciences, 16(1), 4959.

Ben Ahmed C., Ben Rouina B., Sensoy S., Boukhriss M. and Ben Abdullah F. (2010), Exogenous proline effects on photosynthetic performance and antioxidant defense system of young olive tree, Journal of Agricultural and Food Chemistry, 58(7), 4216-4222.

Ben Sekerifa B et Khellafi H. (2018), Effet de la salinité sur quelques traits physiologiques chez Zygophyllum album L, Ph.D. Master, Université Kasdi Merbah Ouargla, Faculté des Sciences de la Nature et de la Vie, Département des Sciences Biologiques.

Bienert G.P., Møller A.L.B., Kristiansen K.A., Schulz A., Møller I.M., Schjoerring J.K. and Jahn T.P. (2007), Specific aquaporins facilitate the diffusion of hydrogen peroxide across membranes, Journal of Biological Chemistry, 282, 1183-1192.

Bienert G.P., Schjoerring J.K. and Jahn T.P. (2006), Membrane transport of hydrogen peroxide, Biochimica et Biophysica Acta-Biomembranes, 1758, 994-1003.

Bois G. (2005), Ecophysiologie de semis de conifères ectomycorhizés en milieu salin et soclique, Ph.D. Thèse, 187p.
Bor M., Ozdemir F. and Turkan I. (2003), The effect of salt stress on lipid peroxidation and antioxidants in leaves of sugar beet Beta vulgaris $\mathrm{L}$. and wild beet Beta maritima L., Plant Science, 164, 77-84

Bradford M.M. (1976). A rapid and sensitive method for the quantitation of microgram quantities of protein utilizing the principle of protein-dye binding, Analytical Biochemistry, 72, 248-254. http://dx.doi.org/10.1016/0003-2697(76)90527-3.

Chen C. and Dickman M.B. (2005), Proline suppresses apoptosis in the fungal pathogen Colletotrichum trifolii, Proceedings of the National Academy of Sciences of the United States of America, 102(9), 3459-3464.

Chen H. and Jiang J.G. (2010), Osmotic adjustment and plant adaptation to environmental changes related to drought and salinity, Environmental Review, 18, 309-319.

Da Costa P.H.A., Neto A.D.A., Bezerra M.A., Prisco J.T. and GomesFilho E. (2005), Antioxidant-enzymatic system of two sorghum genotypes differing in salt tolerance, Braz. Journal of Plant Physiology, 17, 353-361

Dat J.F., R. Pellinen R., Beeckman T., Van De Cotte B., Langebartels C., Kangasjarvi J., Inze D. and Van Breusegem F. (2003), Changes in hydrogen peroxide homeostasis trigger an active cell death process in tobacco, Plant Journal, 33, 621-632.

Dewanto V., Wu X., Adom K.K. and Liu R.H. (2002), Thermal processing enhances the nutritional value of tomatoes by increasing total antioxidant activity, Journal of Agricultural and Food Chemistry, 50, 3010-3014.

Dos Santos A., Silva-Mann R., Ferreira R., \& Brito A. (2010), Water pre-hydration as priming for Moringa oleifera Lam. seeds under salt stress. Tropical and Subtropical Agroecosystems, 14(1), 201-207.

Douaoui A. and Hartani T. (2008), Impact de l'irrigation par les eaux souterraines sur la dégradation des sols de la plaine du Bas-Chellif, Scientific Commons, 2(3), 9.

Dreier W. and Goring M. (1974), Dereinflus shoher Salzkonzentration en auf Verschied en ephysiologische parameter Von Maiswurzeln. Naturwiss, 23, 641-644.

El-Dabh R.S., El-Khateeb M.A., Mazher A.A.M. and Abd El-Badaie A.A. (2011), Effect of salinity on growth and chemical constituents of Moringa oleifera L. Bulletin of Faculty of Agriculture Cairo University, 62(3), 261-386.

Gallé A., Haldimann P. and Feller, U. (2007), Photosynthetic performance and water relations in young pubescent oak (Quercus pubescens) trees during drought stress and recovery, New Phytologist, 174(4), 799-810

Gao Y., Yao Y., Zhu Y. and Ren G. (2015), Isoflavone content and composition in chickpea (Cicer arietinum L.) sprouts germinated under different conditions, Journal of Agricultural and Food Chemistry, 63, 2701-2707.

Gill S.S. and Tuteja N. (2010), Reactive oxygen species and antioxidant machinery in abiotic stress tolerance in crop plants, Plant Physiology and Biochemistry, 48(12), 909930.

Gill S.S. and Tuteja N. (2011), Reactive oxygen species and antioxidant machinery in abiotic stress tolerance in crop plants, Plant Physiology and Biochemistry, 48, 909-930.

Goldsworthy G.J., Mordue W. and Guthkelch J. (1972), Studies on insect adipokinetic hormones, General and Comparative Endocrinology, 18, 545-551.

Gondim F.A., Gomes-Filho E., Costa J.H., Mendes Alencar N.L. and Prisco J.T. (2012), Catalase plays a key role in salt 
stress acclimation induced by hydrogen peroxide pretreatment in maize, Plant Physiology and Biochemistry, 56, $62-71$.

Guardado-Félix D., Serna-Saldivar S.O., Cuevas-Rodríguez E.O., Jacobo-Velázquez D.A. and Gutiérrez-Uribe J.A. (2017). Effect of sodium selenite on isoflavonoid contents and antioxidant capacity of chickpea (Cicer arietinum L.) sprouts, Food Chemistry, 226, 69-74.

Hajlaoui H., Denden M. and Bouslama M. (2007), Etude de la variabilité intraspécifique de tolérance au stress salin du pois chiche (Cicer arietinum L.) au stade germination, Tropicultura, 25, 168-173.

Hakiman M. and Maziah M. (2010), Non-enzymatic and enzymatic antioxidant activities in aqueous extract of differ-ent Ficus deltoidea accessions, Jorunal of Medicinal Plants Research, 3, 120-131.

Hegazi M.A. (2015), Influence of Soil Type, Sowing Date and Diluted Seawater Irrigation on Seed Germination, Vegetation and Chemical Constituents of Moringa oleifera, Lam, Journal of Agricultural Science, 7, 1916-9760. http://dx.doi.org/ 10.5539/jas.v7n3p138.

Hernandez J.A. and Almansa M.S. (2002), Short-term effects of salt stress on antioxidant systems and leaf water relations of pea leaves, Physiologia Plantarum, 115, 251-257.

Hernández J.A. Jiménez A., Mullineaux P. and Sevilia F. (2000), Tolerance of pea (Pisum sativum L.) to long-term salt stress is associated with induction of antioxidant defenses, Plant, Cell \& Environment, 23(8), 853-862.

Houle G., Morel L., Reynolds C.E. and Siégel J. (2001), The effect of salinity on different developmental stages of an endemic annual plant, Aster laurentianus (Asteraceae), American Journal of Botany, 88(1), 62-67.

Hussein M.M. and Abou-Baker N.H. (2014), Growth and mineral status of Moringa plants as affected by silicate and salicylic acid under salt stress, IJPSS, 3(2), 163-177. http://dx.doi. org/10.9734/IJPSS/201 4/6105

ISTA Association Internationale de Tests de Semences. (2014), Règles des propositions pour les règles internationales pour les tests de semences, Comité exécutif. Bassersdorf, Suisse. $\mathbf{5 3}$ p.

Joseph B. and Jini D. (2011), Development of salt stress-tolerant plants by gene manipulation of antioxidant enzymes, Asian Journal of Agricultural Research, 5(1), 17-27.

Karoune S. (2016), Etude Ecophysiologique et Phytochimique de deux espèces d'Acacia: Acacia albida et Acacia raddiana, Ph.D. Thèse, Université des Frères Mentouri Constantine, Faculté des Sciences de la Nature et de la Vie (Algérie).

Kartashov A., Radyukina N., Ivanov Y.V., Pashkovskii P., Shevyakova N. and Kuznetsov V.V. (2008), Role of antioxidant systems in wild plant adaptation to salt stress, Russian Journal of Plant Physiology, 55(4), 463-468.

Kaya C., Ashraf M., Dikilitas M. and Tuna A.L. (2013), Alleviation of salt stress-induced adverse effects on maize plants by exogenous application of indole acetic acid (IAA) and inorganic nutrients-a field trial, Australian Journal of Crop Science, 7(2), 249-254.

Khalifa F.K., Khalil F.A., Barakat H.A. and Hassan M.M. (2011), Protective role of wheat germ and grape seed oils in chlorpyrifos-induced oxidative stress, biochemical and histological alterations in liver of rats, Australian Journal of Basic and Applied Sciences, 5(10), 54-66.
Koyro H.W., Ahmad P. and Geissler N. (2012), Abiotic stresses ponses in plants: an overview. In: Ahmad P., Prasad MNV, editors. Environmental adaptations and stress tolerance of plants in the era of climate change, New York (NY), Springer Science+Business Media, 1-28.

Ksouri R., Megdiche W., Koyro H.W. and Abdelly C. (2010), Responses of halophytes to environmental stresses with special emphasis to salinity, Advances in Botanical Research, 53, 117-145.

Laleye O.A.F., Ahissou H., Olounlade A.P., Azando E.V.B. and Laleye A. (2015), Etude bibliographique de trois plantes antidiabétiques de la flore béninoise: Khaya senegalensis (Desr) A. Juss (Meliaceae), Momordica charantia Linn (Cucurbitaceae) et Moringa oleifera L (Moringaceae). International Journal of Biological and Chemical Sciences, 9(5), 2682-2700.

Latef A.A. and Chaoxing H. (2014), Does the inoculation with Glomus mosseae improves salt tolerance in pepper plants? Journal of Plant Growth Regulation, 33, 644-653.

Leone A., Spada A., Battezzati A., Schiraldi A., Aristil J. and Bertoli S. (2015), Cultivation, genetic, ethnopharmacology, phytochemistry and pharmacology of Moringa oleifera leaves: An overview, International journal of molecular sciences, 16(6), 12791-12835.

Li L., Liu X., Peijnenburg W.J.G.M., Zhao J., Chen, Yu J. and H. Wu H. (2012), Pathways of cadmium fluxes in the root of the halophyte Suaeda salsa, Ecotoxicology and Environmental Safety, 75, 1-7.

Lim T.K. (2015), Edible Medicinal and Non-Medicinal Plants, http://dx.doi.org/10.1007/978-94-017-9511-1.

Liu Z., Crampton M., Todd A. and Kalavacharla V. (2012), Identification of expressed resistance gene-like sequences by data mining in 454-derived transcriptomic sequences of common bean (Phaseolus vulgaris L.), BMC Plant Biology, 12(1), 42.

Løvdal T., Olsen K.M., Slimestad R., Verheul M. and Lillo C. (2010), Synergetic effects of nitrogen depletion, temperature, and light on the content of phenolic compounds and gene expression in leaves of tomato, Phytochemistry, 71(5), 605613.

Mâalem S. (2011), Etude de l'impact des interactions entre le phosphore et le Chlorure de Sodium sur trois espèces végétales halophytes du genre Atriplex (A. halimus, $A$. canescens et $A$. nummularia), Ph.D. Thèse, Université Badji Mokhtar-Annaba, pp. 96-97.

Majumder A.L., Sengupta S. and Goswami L. (2010), Osmolyte regulation in abiotic stress, Chap. 16, Dans Abiotic stress adaptation in plants: Physiological, molecular and genomic foundation, Sous la direction de Pareek A., Sopory S.K., Bohnert H.J. et Govindjee, pp. 349-370.

Mc Cord J.M. (2000), L'évolution des radicaux libres et du stress oxydatif, American Journal of Medicine, 108, 652-659

Mendoza-Sánchez M., Guevara-G R.G., Castaño-T E., Mercado-S E.M., Acosta-G J.A., Rocha-G N.E. and Reynoso-Camacho R. (2016), Effect of chemical stress on germination of cv Dalia bean (Phaseolus vulgaris L) as an alternative to increase antioxidant and nutraceutical compounds in sprouts, Food Chemistry, 212, 128-137.

Mhadhbi H., Fotopoulos V., Djebali N., Polidoros A.N. and Aouani1 M.E. (2009), Behaviours of Medicago truncatulaSinorhizobium meliloti Symbioses under Osmotic Stress in 
Relation with the Symbiotic Partner Input: Effects on Nodule Functioning and Protection, Journal of Agronomy and Crop Science, 195, 225-231.

Mhadhbi H., Jebara M., Limam F. and Aouani M.E. (2004), Rhizobial strain involvement in plant growth, nodule protein composition and antioxidant enzyme activities of chickpearhizobia symbioses: modulation by salt stress, Plant Physiology and Biochemistry, 42, 717-722.

Mhadhbi H., Jebara M., Zitoun A., Limam F. and Aouani M.E. (2008), Symbiotic effectiveness and response to mannitol mediated osmotic stress of various chickpea-rhizobia associations, World Journal of Microbiology and Biotechnology, 24, 1027-1035.

Mittler R. (2002), Stress oxydant, antioxydants et tolérance au stress, Tendance Plant Science, 7, 405-410.

Munns R. and Tester M. (2008), Mechanism of salinity tolerance, Annual Review of Plant Biology, 59, 651-81.

Nagalakshmi N. and Prasad M.N.V. (2001), Responses of glutathione cycle enzymes and glutathione metabolism to copper stress in Scenedesmus bijugatus, Plant Science, 160, 291-299. https://doi. org/10.1016/S0168-9452 (00)00392-7.

Nakano Y. and Asada K. (1981), Hydrogen peroxide is scavenged by ascorbate specific peroxidase in spinach chloroplasts, Plant and Cell Physiology, 22, 867-880.

Nijveldt R.J., Van Nood E., Van Hoorn D.E., Boelens P.G., Van Norren K. and Van Leeuwen P.A. (2001), Flavonoids: a review of probable mechanisms of action and potential applications, The American Journal of Clinical Nutrition, 74(4), 418-425.

Noreen F., Muhammad A., Muhammad S., Ghulam A., Mubshar H., Muhammad N. Allah W., Muhammad T. and Mauhammad A. (2018), Germination, growth and ions uptake of Moringa (Moringa oleifera L.) grown under saline condition, Journal of Plant Nutrition Volume, 41(12), 1555-1565.

Nouman W., Siddiqui M.T., Basra S.M.A., Khan R.A., Gull T., Olson M.E. and Munir H. (2012), Réponse du Moringa oleifera aux conditions salines, International Journal of Agriculture And Biology, 14(5), 757-762.

Novillo P., Salvador A., Llorca E., Hernando I. and Besada C. (2014), Effect of $\mathrm{CO}_{2}$ deastringency treatment on flesh disorders induced by mechanical damage in persimmon, Biochemical and microstructural studies. Food Chemistry, 145, 454-463. https://doi.org/10.1016/j.foodchem.2013.08.054.

Okuda T. (2005), Systematics and health effects of chemically distinct tannins in medicinal plants, Phytochemistry, 66(17), 2012-2031.

Olagbemide P.T. and Alikwe Ph.C.N. (2014), Proximate Analyses, Chemical Composition of Raw, and Defatted Moringa oleifera Kernel, Advances in life Science and Technology, 24.

Olson M.E. and Carlquist S. (2001), Stem and root anatomical correlations with life form diversity, ecology, and systematics in Moringa (Moringaceae), Botanical Journal of the Linnean Society, 135(4), 315-348.

Oluduro A.O., Ambrose D.C.P., Abiodun O. and Daunty A.L. (2016), Moringa, In D.C.P. Ambrose et al. (Ed.), Leafy Medicinal Herbs: Botany, Chemistry, Postharvest Technology and Uses, Wallingford: CAB International, pp. 163-169.

Osman H.E. and Abohassan A.A. (2012), Morphological and analytical characterization of Moringa peregrine populations in western Saudi Arabia, International Journal of Theoretical and Applied Sciences, 4, 174-184.
Pandey A., Pradheep K., Gupta R., Nayar E.R. and Bhandari D.C. (2011), Drumstick tree (Moringa oleifera Lam.): A multipurpose potential species in India, Genetic Resources and Crop Evolution, 58(3), 453-460. http://dx.doi.org/10.1007/s10722-010-9629-6.

Parent C., Capelli N. and James D. (2008), Formes réactives de l'oxygène, stress et mort cellulaire chez les plantes, $C$. $R$. Biologies, 331, 255-261.

Parvaiz A., Munir O., Satyawati S. and Salih G. (2014), Effect of sodium carbonate-induced salinity-alkalinity on some key osmoprotectants, protein profile, antioxidant enzymes, and lipid peroxidation in two mulberry (Morus alba L.) cultivars, Journal of Plant Interactions, 9(1), 460-467. DOI: 10.1080/17429145.2013.855271.

Prado f.E., Boero C., Gallardo M. and Gonzalez J.A. (2000), Effect of $\mathrm{NaCl}$ on germination, growth and soluble sugar content in Chenopodium quinoa Willd. Seeds, Botanical Bulletin of Academia Sinica, 41, 27-34.

Prieto P., Pineda M. and Aguilar M. (1999), Spectrophotometric quantitation of antioxidant capacity through the formation of a phosphomolybdenum complex: Specific application to the determination of vitamin E, Analytical Biochemistry, 269, 337-341.

Quashie ML A and Tchezoum YA. (2009), Étude de la germination de Moringa oleifera (Lam) Afrique Science, 05(3), 169-180. ISSN:1813-548X.

Rachidai A., Driouich A., Ouassou A. and El Hadrami I. (1994), Effect of salt stress on the germination of durum wheat (Triticum durum Desf), Revenue Improvement Production of Agriculture, 6, 209-228.

Rejili M., Vadelm A. and Neffatp M. (2006), Germinal behavior of two populations of Lotus creticus (L.) in the presence of $\mathrm{NaCl}$, Revue des Régions Arides, 1(17), 65-78.

Rivas R., Oliveira M.T, and dos Santos M.G. (2013), Three cycles of water deficiency of seedlings of Moringa oleifera woody species improvement stress tolerance Plant Physiology and Biochemistry, 63, 200-208.

Roxas V.P., Lodhi S.A., Garret D.K., Mahan J.R., and Allen R.D. (2000), Stress tolerance in transgenic tobacco seedlings that overexpress gluthatione S-transferase/gluthatione peroxidase, Plant Cell Reports, 41, 1229-1234.

Sakihama Y., Cohen M.F., Grace S.C. and Yamasaki H. (2002), Plant phenolic antioxidant and prooxidant activities: phenolicsinduced oxidative damage mediated by metals in plants, Toxicology, 177, 67-80.

Selma B., Mohamed T. and Aicha B. (2015), Study of phenolic composition of leaves of Brassica napus L. facing the water deficit, Bulletin of the Scientific Institute, Rabat, Life Sciences Section, 36, 9-16.

Sharma V.R., Paliwal P. and Sharma S. (2011), Sharma Analyse phytochimique et évaluation des activités antioxydantes de l'extrait hydroéthanolique de Moringa oleifera Lam, Gousses Journal of Pharmaceutical Research, 4, 554-557.

Silva E.C.A. da, Lucena P.G.C. de, Nascimento R.M. do, Santos C.A. dos, Araújo R.P.S. de, and Nogueira R.J.M.C. (2017), Mecanismos bioquímicos em Moringa oleifera Lam. para tolerância à salinidade. Acta Iguazu, 6(4), 54-71.

Singh R.S.G., Negi P.S. and Radha C. (2013), Phenolic composition, antioxidant and antimicrobial activities of free and bound phenolic extracts of Moringa oleifera seed flour, Journal of Functinal Foods, 5, 1883-1891. 
Singh S.C., Sinha R.P. and Hader D.P. (2002), Role of lipids and fatty acids in stress tolerance in cyanobacteria, Acta Protozoologica, 41, 297-308.

Spranger I., Sun B., Mateus A.M., De Freitas V., Jorge M. and DaSilva R. (2008), Chemical characterization and antioxidant activities of oligomeric and polymeric procyanidin fractions from grape seeds, Food chemistry, 108, 519-532.

Sudhakar C., Lakshmi A. and Giridara kumar S. (2001), Changes in the antioxidant enzymes efficacy in two high yielding genotypes of mulberry (Morus alba L.) under $\mathrm{NaCl}$ salinity, Plant Science, 161, 613-619.

Sun B., Richardo-da-Silvia J.M. and Spranger I. (1998), Critical factors of vanillin assay for catechins and proanthocyanidins, Journal of Agricultural and Food Chemistry, 46, 4267-4274.

Tesfay S.Z., Modi A. and Mohammed F. (2016), The effect of temperature in moringa seed phytochemical compounds and carbohydrate mobilization, South African Journal of Botany, 102, 190-196.

Tian Y., Zeng Y., Zhang J., Yang C.G., Yan L., Wang X.J. and Sheng J. (2015), High quality reference genome of drumstick tree (Moringa oleifera Lam.), a potential perennial crop, Science China Life Sciences, 58(7), 627-638. http://dx.doi.org/10.1007/s11427-015-4872-x.

Troll W. and Lindsley J. (1955), A photometric method for the determination of proline, Journal of Biological Chemistry, 215, 655-660.

Van Breusegem F. and Dat J.F. (2006), Reactive oxygen species in plant cell death, Plant Physiology, 141, 384-390.

Wang X.S. and Han J.G. (2009), Changes of proline content, activity, and active isoforms of antioxidative enzymes in two alfalfa cultivars under salt stress, Agricultural Science China, 8, 431-440.

Xia E.Q., Deng G.F., Guo Y.J. and Li H.B. (2010), Biological Activities of Polyphenols from Grapes, International Journal of Molecular Sciences, 11, 622-646.

Yang T. and Poovaiah B.W. (2002), Hydrogen peroxide homeostasis: activation of plant catalase by calcium/calmodulin, Proceedings of the National Academy of Sciences, 99, 4097-4102.

Yusuf J.,Yuakubu M.B. and Balarabe A.M. (2015), The use of Moringa oleifera seed as a coagulant for domestic water Purification, IOSR Journal of Pharmacy and Biological Sciences (IOSR-JPBS), 10(1), 6-9.

Zhu Z., Wei G., Li J., Qian Q. and Yu J. (2004), Silicon alleviates salt stress and increases antioxidant enzymes activity in leaves of salt-stressed cucumber (Cucumis sativus L.), Plant Science, 167, 527-533.

Zineb M., Fabienne D., Laurence M., Rémi L. and Moulay B. (2015), Study of lipid peroxidation (MDA) and antioxidative activity (POD) in two halophytes: Atriplex halimus L. and Atriplex canescens (Pursh) Nutt under salt effect, International Journal of Innovation and Applied Studies ISSN 2028-9324, 10(1), 450-458. 